\title{
THE PROCESS OF EVALUATING STUDENTS BASED ON UNIVERSITY PROGRAM LEARNING OUTCOMES
}

\author{
Linh Khanh Luu ${ }^{1,+}$, \\ Long Phan ${ }^{2}$
}

\section{Article History}

Received: 05 October 2020

Accepted: 15 November 2020

Published: 30 December 2020

\section{Keywords}

Evaluation, learning

outcomes, training programs, courses, performance indicators

\author{
${ }^{1} \mathrm{Ph} . \mathrm{D}$. student, HCMC University of Technology and Education, Vietnam; \\ ${ }^{2} \mathrm{HCMC}$ University of Technology and Education, Vietnam \\ ${ }^{+}$Corresponding author • Email: luukhanhlinh@ufm.edu.vn
}

\section{INTRODUCTION}

In recent years, thanks to the increasing demands from the labor market, higher education is focusing on targeted or on-demand access to training products through the development of learning outcome standards of the training program in order to design the content of the training program to fully meet the standards and support students to achieve those standards. In fact, the standardization of university-level training programs in many universities in the country tends to be developed in a general and highly integrated manner, thus widening the gap between the learning outcomes' requirements and the actual teaching, testing, and evaluation activities of the module/ subject. To solve this problem, one of the current approaches is to build a system of PI (Performance Indicators) for the program learning outcomes, which refers to teaching and testing activities.

The article briefly studies the relationship between student assessment and other components in the teaching process, Performance Indicator (PI) for the program learning outcomes and its implication in the teaching and assessment activities as well as the process of developing learner's assessment procedure based on learning outcomes through achieving the program learning outcomes' PI.

\section{LITERATURE REVIEW}

According to Ralph W. Tyler (1949), one of the pioneers in approaching educational evaluation based on achievement of goals, assessment should be placed in the close connection between three main elements of the teaching process: program objectives, learning experience and student assessment. If assessment is the focus of learning, the assessment criteria of students' real ability are based on 5 orientations: (1) positive attitude and learning awareness; (2) integrating knowledge; (3) expanding and refining knowledge; (4) using meaningful knowledge and (5) developing thinking routine.

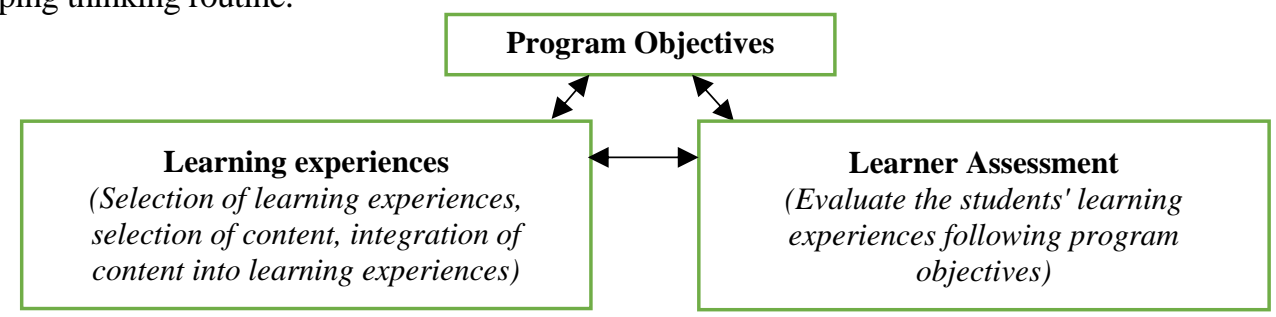

Figure 1. Relationship between 3 factors of teaching activities by Ralph W. Tyler (1949) 
Ralph W. Tyler, John Biggs (2009) implied that the teaching process is comprehensively reflected in three main factors linked together in a systematic way (constructive alignment), which are: learning outcomes, teaching and learning activities, and assessment method, in which the learning outcomes is the basis for designing teaching and learning activities and the target of the assessment. Each learning outcome can be measured using many different forms of assessment (Biggs \& Tang, 2009).

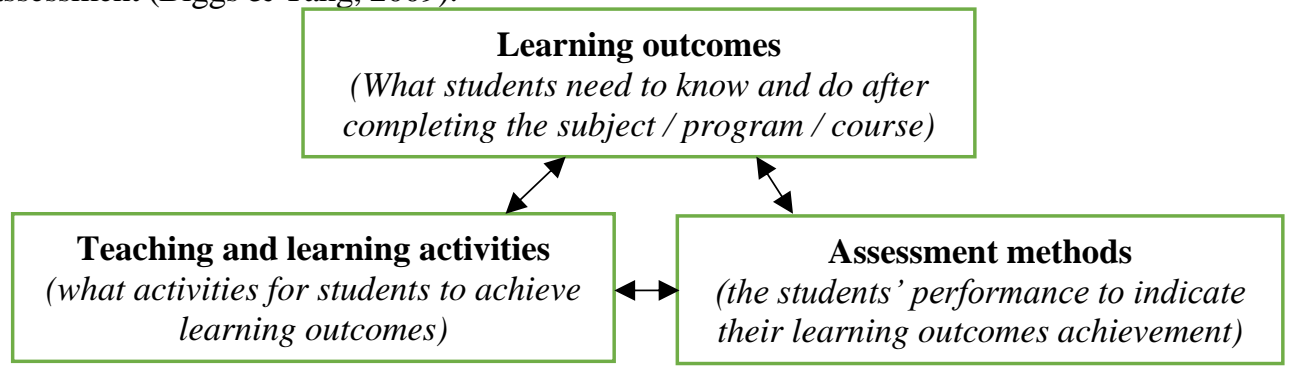

Figure 2. The constructive alignment between 3 factors of teaching activities by (Biggs \& Tang, 2009)

In recent years, target-oriented education is clearly shown in the outcomes-based education model, which is widely applied in the world. The organization for evaluating the educational quality under the ASEAN University Network Quality Assurance (AUN-QA) has concretized the model of outcomes-based education for the training program level according to the diagram shown in Figure 3 below:

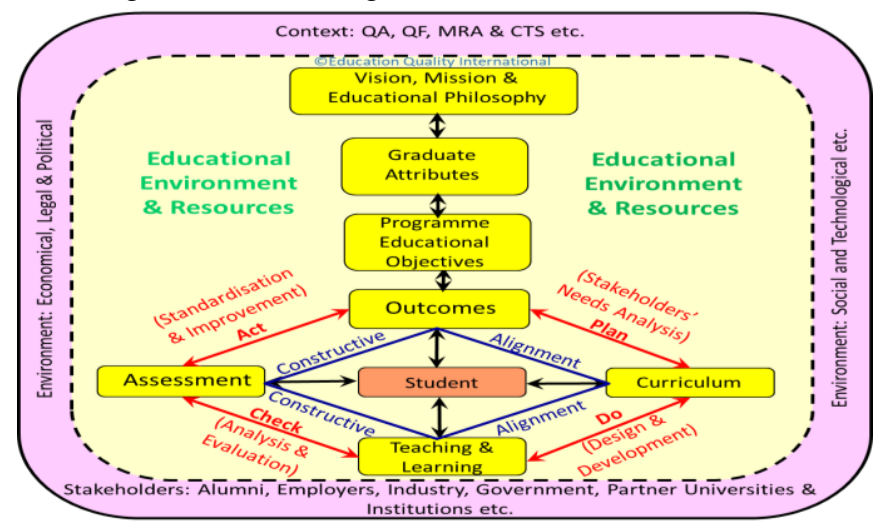

Figure 3. Compatibility of core elements of the training program (Ong Chee Bin, 2018)

According to this model, the learning outcomes are developed based on the mission, vision, educational philosophy, requirements for graduates, and the objectives of the training program. At the same time, learning outcomes orientate the design of teaching program content, teaching and learning activities, and assessment methods. Assessment is a step to collect information and data on students' achievements in order to review teaching and learning activities, and whether the program content is suitable for the requirements of the learning outcomes, thereby taking measures for improvements. Evaluation of students' learning outcomes achievements is conceptualized in Figure 4 below:

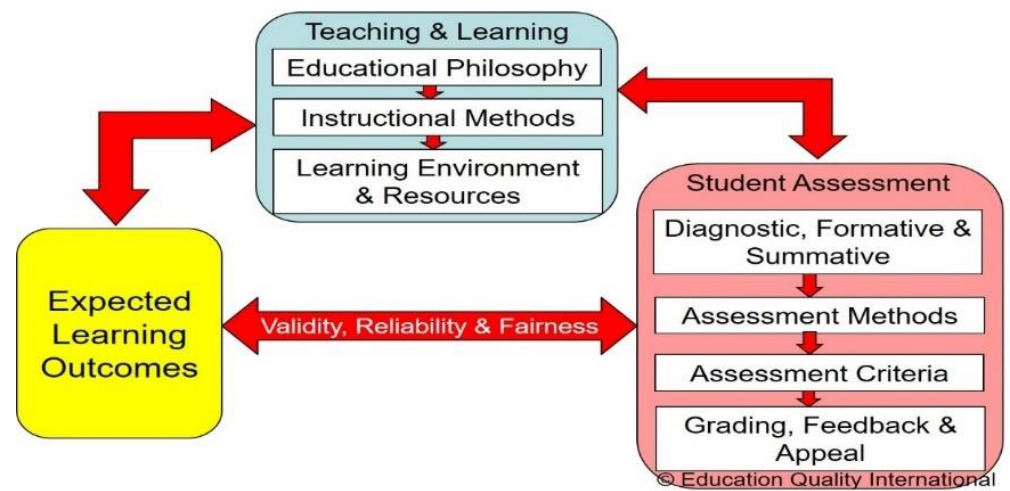

Figure 4. Relationship of student assessment, teaching \& learning, learning outcomes (Ong Chee Bin, 2018) 
One of the necessary factors to evaluate learners is to build evaluation criteria so that the learning outcomes can be evaluated. To perform outcomes-based evaluation, the evaluation criteria must be shown in the form of Performance Indicators.

In Vietnam, the phrase "learning outcomes" is used by the Ministry of Education and Training in Official Dispatch No. 2196/BGDDT-GDDH dated 22/4/2010 on guidelines for building and announcing the university learning outcomes and the Circular. No. 04/2016/TT-BGDDT dated March 14, 2016 promulgating the regulation on quality assessment standards of training programs at university level. Thereby, the Ministry of Education and Training has directed educational institutions to teach, examine and evaluate the learning outcomes to meet the published training program standards; however, evaluating the learning outcomes effectively remains a challenge of the universities. Therefore, universities need to build a system of performance indicators (PI) of the learning outcomes for a number of reasons as follows:

- The distribution of the program learning outcomes throughout the learning outcomes of each course is highly generalized, sometimes the learning outcomes consisting of both knowledge and skills is difficult to measure;

- The PI system helps to concretize the learning outcomes setting according to the better weighted and observable expectations, compared with the standard measurement;

- The PI system of the training program learning outcomes can effectively support the design of the training program framework; arrangement in the modules and the training program learning outcomes; selection of appropriate teaching, testing, evaluation and learning activities methods.

Regarding the outcomes-based evaluation, the studies in this direction are still quite modest; however, there are some typical domestic and international studies as follows:

- Le Ngoc Quynh Lam (2017) proposed a set of KPIs to help managers effectively manage and operate the learning outcomes over time so that decisions can be made based on the collected database;

- Alzubaidi (2017) proposed a solution to build KPI for the program learning outcomes and the implications to the conceptual assessment of the results of the student's achievement of those learning outcomes;

- Sharma (2019) introduced a mathematical model to evaluate the achievement of the program learning outcomes and its specific modules through the KPI system;

- Ayadat (2020) introduced the results of research on the combination of KPI and rubric to evaluate the level of learners achieving the learning outcomes of training program.

\section{RESEARCH METHODS AND RESULTS}

\subsection{Research methods}

- Desk research method: Collect, analyze, arrange and synthesize documents from domestic and foreign scientific research, specialized documents, articles, relevant scientific reports of the research issues, from which creates a foundation for theoretically and practically analyzing, comparing the learning outcome assessment, finding theoretical and practical problems to deepen the research related to the assessment of the achievement level through evaluating the learning outcomes of students.

- Expert interviewing method: Recognizing exchanged opinions, contributions, comments of scientists, administrators, lecturers with experience in teaching, assessing learning outcomes at universities.

- Methods of observation and research of educational products: Design evaluation, implementation of assessment, studying the structure of exam questions, content of exam questions, training program and training program, detailed outlines of subjects, the learning results of students ... to better understand the situation of evaluating the learning outcomes in general and evaluating the learning results according to the program learning outcomes in particular.

\subsection{Research results}

\subsubsection{Necessity of program learning outcomes}

Measuring and evaluating the achievement level of the learning outcomes is highly necessary for the following reasons: - To determine the degree of achieving learners' knowledge, skills and attitudes compared to the objectives and requirements of the training program; - To make public statements about students' competencies and learning outcomes, create opportunities for students with self-assessment skills, help students realize their progress, encourage, motivate better learning; - To help teachers have a practical basis to recognize their strengths and weaknesses, self-adjust and perfect teaching activities; - To meet the requirements of the training program quality accreditation according to domestic and regional standards. 


\subsubsection{Performance indicators of learning outcomes}

PI indicators are basically a set of indicators that measure the performance of an organization or a unit.

For universities, these indicators will help the university evaluate the level of fulfillment of the tasks, and thus the university board of management will make the correct decisions to improve the overall quality of performance in general and each training program in particular. PI is also used when comparing training programs or comparing a training program with specific quality standards.

For the training program, performance evaluation indicators are specific measurable requirements that learners must meet to achieve the Program Learning Outcomes (PLO) standards. Performance evaluation indicators can be measured through evidence, data or through Course Learning Outcomes (CLO). The indicators for evaluating the results of the implementation of the problem solving help to form the teaching and learning content, teaching and learning methods, the evaluation and testing methods and content more clearly. Through the results of achieving these PI indicators, students will recognize how much they perceive themselves and gain knowledge compared to the proposed learning outcomes.

\subsubsection{Requirements for students to achieve the learning outcomes of the program}

The evaluation of the program learning outcomes consists of various contents about knowledge and skills that can be done through the evaluation of PIs. When evaluating the program learning outcomes, it is necessary to: - Determine the achievement criteria (Criterion): Helps determine if the student has achieved the program learning outcomes, in which it is necessary to specify the level of score or rating that the students needs to achieve to be considered as the satisfaction of the learning outcomes; - Determine the target level (Target): Before measuring and assessing the program learning outcomes, it is necessary to determine the proportion of students in the course that will meet the learning outcomes or the PIs. Setting goals will allow teachers to make an initial comparison between actual achievement and target, and make further comparisons between years when data is available over many years. For example, at least $80 \%$ of students achieved a $\mathrm{C}$ in the final exam.

3.2.4. Process of student assessment based on learning outcomes of the program

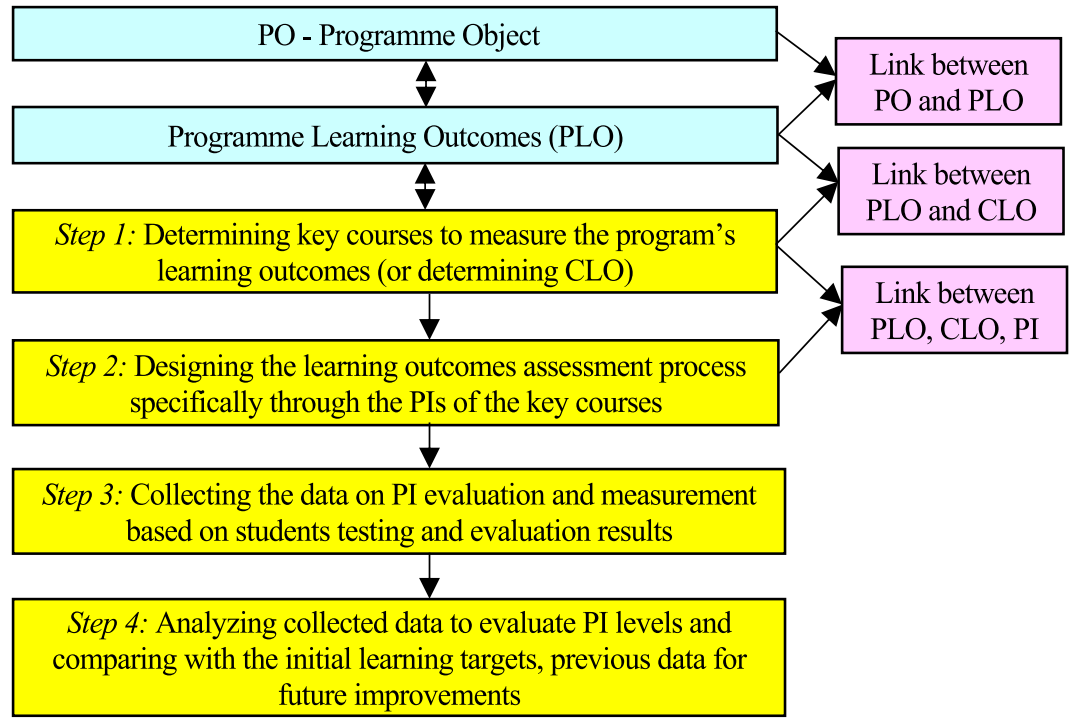

Figure 5. The process of evaluating students based on program learning outcomes

The program learning outcomes must have a connection with the objectives of the training program. From the program learning outcomes, the lecturers design the corresponding learning outcomes, teaching methods as well as testing and evaluation methods. The steps to measure and evaluate the achievement level of the learning outcomes can be processed as follows:

Step 1: Determine the key courses that need to collect evidences for the assessment of the program learning outcomes based on the skill matrix.

In the training program, there are many courses of different knowledge blocks, the task of each course is to contribute to the formation of the comprehensive learning outcomes of knowledge, skills, and attitudes when students finish the 
program. It can also be said that each course has a different level of contribution. After completing the courses, students will achieve the learning outcomes of each course, and thereby gradually achieve the learning outcomes of the published training program. Therefore, it is necessary to establish a relationship between the course learning outcomes and the program learning outcomes. For example, in Table 1, course A contributes to achieving the program learning outcomes as PLO1, PLO3, PLO5, PLO7, PLO9, PLO10 and not related to PLO2, PLO4, PLO6, PLO8. In Table 2, course B contributes to the achievement of the program learning outcomes as PLO2, PLO4, PLO6, PLO7, PLO8, PLO10.

Table 1. Relationship between the learning outcomes of course A and program learning outcomes

\begin{tabular}{ccccccc}
\hline & & & \\
\end{tabular}

Similar to courses A and B, the relationship between CLO of other courses and the PLO is determined, and all the relationships are synthesized in the skills matrix as Table 3 below.

Table 3. Relationships of the learning outcomes of the program (skill matrix)

\begin{tabular}{|c|c|c|c|c|c|c|c|c|c|c|}
\hline Course $P$ & PLO1 & PLO2 & PLO3 & PLO4 & PLO5 & PLO6 & PLO7 & PLO8 & PLO9 & PLO10 \\
\hline Course A & $\begin{array}{c}\mathrm{X}- \\
\text { Introdu- } \\
\text { ction }\end{array}$ & & $\begin{array}{c}\mathrm{X}- \\
\text { Assess- } \\
\text { ment }\end{array}$ & & $\begin{array}{c}\mathrm{X}^{-} \\
\text {Assess- } \\
\text { ment }\end{array}$ & & $\begin{array}{c}\mathrm{X}- \\
\text { Assess- } \\
\text { ment }\end{array}$ & & $\begin{array}{c}\mathrm{X}^{-} \\
\text {Introdu } \\
\text { ction }\end{array}$ & $\begin{array}{c}\mathrm{X}- \\
\text { Assess- } \\
\text { ment }\end{array}$ \\
\hline Course B & & $\begin{array}{c}\mathrm{X}^{-} \\
\text {Assess- } \\
\text { ment }\end{array}$ & & $\begin{array}{c}\mathrm{X}^{-} \\
\text {Introdu- } \\
\text { ction }\end{array}$ & & $\mathrm{X}$ & $\begin{array}{c}\mathrm{X}^{-} \\
\text {Assess- } \\
\text { ment }\end{array}$ & $\begin{array}{c}\mathrm{X}^{-} \\
\text {Assess- } \\
\text { ment }\end{array}$ & $\begin{array}{c}\mathrm{X}^{-} \\
\text {Assess- } \\
\text { ment }\end{array}$ & $\begin{array}{c}\mathrm{X}^{-} \\
\text {Assess- } \\
\text { ment }\end{array}$ \\
\hline
\end{tabular}

Course ...

Course $n$

Step 2: Designing the learning outcomes assessment process specifically through the PIs of the key courses

Depending on the contribution of the course in achieving the learning outcomes of the program, the content of the course is only introduced in the teaching process or is focused on teaching and carefully evaluated. Thus, the contents of the courses that need to be assessed are necessarily related to the learning outcomes of the course and the training program. In addition, not all content related to learning outcomes is assessed by the end-of-term exam with high weight; some content related to PIs at low cognitive level (on Bloom scale) will be evaluated through regular assignments, short questions and answers in class. 
Table 4. Learning outcomes assessment process of the training program

\begin{tabular}{|c|c|c|c|c|c|c|c|c|c|c|}
\hline PLO & PI & $\begin{array}{c}\text { Key } \\
\text { course }\end{array}$ & $\begin{array}{c}\text { Time of } \\
\text { evaluation }\end{array}$ & $\begin{array}{l}\text { Evaluation } \\
\text { tool }\end{array}$ & $\begin{array}{c}\text { Evaluation } \\
\text { method }\end{array}$ & $\begin{array}{c}\text { Data } \\
\text { collector }\end{array}$ & $\begin{array}{c}\text { Passing } \\
\text { target }\end{array}$ & $\begin{array}{c}\text { Target } \\
\text { (Stimulated } \\
\text { figures) }\end{array}$ & $\begin{array}{c}\text { Actual } \\
\% \text { of } \\
\text { students } \\
\text { passing }\end{array}$ & Comment \\
\hline \multirow{4}{*}{$\begin{array}{c}\text { PLO7 } \\
\text { with } 4 \\
\text { indicators } \\
\text { to achieve } \\
\text { learning } \\
\text { outcome }\end{array}$} & $\begin{array}{l}\text { PLO7- } \\
\text { PI } 1\end{array}$ & $\begin{array}{c}\text { Course } \\
\text { A }\end{array}$ & 2020 & Rubric & Final exam & $\begin{array}{l}\text { Course } \\
\text { lecturer }\end{array}$ & $\begin{array}{l}\text { Passing } \\
\text { from } \\
\text { grade } \mathrm{C} \\
\text { of } \\
\text { rubric }\end{array}$ & $\begin{array}{l}80 \% \text { of } \\
\text { students } \\
\text { passing }\end{array}$ & & \\
\hline & $\begin{array}{l}\text { PLO7- } \\
\text { PI } 2\end{array}$ & $\begin{array}{c}\text { Course } \\
\text { B }\end{array}$ & 2020 & Rubric & Thesis & $\begin{array}{l}\text { Course } \\
\text { lecturer }\end{array}$ & $\begin{array}{l}\text { Passing } \\
\text { from } \\
\text { grade } \mathrm{C} \\
\text { of } \\
\text { rubric }\end{array}$ & $\begin{array}{l}85 \% \text { of } \\
\text { students } \\
\text { passing }\end{array}$ & & \\
\hline & $\begin{array}{l}\text { PLO7- } \\
\text { PI } 3\end{array}$ & $\begin{array}{c}\text { Course } \\
\text { B }\end{array}$ & 2020 & Rubric & $\begin{array}{c}\text { Group } \\
\text { assignment }\end{array}$ & $\begin{array}{l}\text { Course } \\
\text { lecturer }\end{array}$ & $\begin{array}{l}\text { Passing } \\
\text { from } \\
\text { grade } \mathrm{C} \\
\text { of } \\
\text { rubric }\end{array}$ & $\begin{array}{l}90 \% \text { of } \\
\text { students } \\
\text { passing }\end{array}$ & & \\
\hline & $\begin{array}{l}\text { PLO7- } \\
\text { PI } 4\end{array}$ & $\begin{array}{c}\text { Course } \\
\text { A }\end{array}$ & 2020 & Rubric & $\begin{array}{l}\text { Individual } \\
\text { assignment }\end{array}$ & $\begin{array}{l}\text { Course } \\
\text { lecturer }\end{array}$ & $\begin{array}{l}\text { Passing } \\
\text { from } \\
\text { grade } \mathrm{C} \\
\text { of } \\
\text { rubric } \\
\end{array}$ & $\begin{array}{l}95 \% \text { of } \\
\text { students } \\
\text { passing }\end{array}$ & & \\
\hline
\end{tabular}

Step 3: Collecting the data on PI evaluation and measurement based on students testing and evaluation results

Synthesizing the courses' testing and evaluation results of all students to have sufficient information and data for the following steps.

Table 5. Statistics of PI achievement evaluation results for PLO7

\begin{tabular}{cccccc}
\hline Course & PI of PLO7 & Grade A & Grade B & Grade C & Grade D \\
\hline \multirow{2}{*}{ Course A } & POL7-PI 1 & $\ldots$ students & $\ldots$ students & $\ldots$ students & $\ldots$ students \\
\cline { 2 - 6 } & POL7-PI 4 & $\ldots$ students & $\ldots$ students & $\ldots$ students & $\ldots$ students \\
\hline \multirow{2}{*}{ Course B } & PLO7-PI 2 & $\ldots$ students & $\ldots$ students & $\ldots$ students & $\ldots$ students \\
\cline { 2 - 6 } & PLO7-PI 3 & $\ldots$ students & $\ldots$ students & $\ldots$ students & $\ldots$ students \\
\hline
\end{tabular}

Step 4: Analyzing collected data to evaluate PI levels and comparing with the initial learning targets, previous data for future improvements.

From the statistics in step 3 (Table 5), synthesize and analyze collected data (Table 6) to draw the graph of the percentage of students achieving PI to compare with the initial learning targets of PLO7-PI 1, PLO7-PI 2, PLO7-PI 3, PLO7-PI 4 (Table 1).

Table 6. Percentage of students achieving PI in comparison with the targets

\begin{tabular}{|c|c|c|c|c|c|c|c|c|c|c|c|c|}
\hline \multirow[b]{2}{*}{$\begin{array}{l}\text { PI of } \\
\text { PLO7 }\end{array}$} & \multicolumn{5}{|c|}{$\begin{array}{c}\text { Number of students in each grading } \\
\text { category }\end{array}$} & \multicolumn{5}{|c|}{$\%$ of students in each grading category } & \multicolumn{2}{|c|}{$\begin{array}{c}\text { Passing \% } \\
\text { (Stimulated data) }\end{array}$} \\
\hline & Total & $\begin{array}{l}\text { Grade } \\
\text { A }\end{array}$ & $\begin{array}{l}\text { Grade } \\
\text { B }\end{array}$ & $\begin{array}{l}\text { Grade } \\
\text { C }\end{array}$ & $\begin{array}{l}\text { Grade } \\
\text { D }\end{array}$ & Total & $\begin{array}{l}\text { Grade } \\
\text { A }\end{array}$ & $\begin{array}{l}\text { Grade } \\
\text { B }\end{array}$ & $\begin{array}{l}\text { Grade } \\
\text { C }\end{array}$ & $\begin{array}{l}\text { Grade } \\
\text { D }\end{array}$ & $\begin{array}{c}\text { Grade } \\
\text { A, B, C } \\
\text { (Pass) }\end{array}$ & $\begin{array}{c}\text { Grade } \\
\text { D } \\
\text { (Fail) } \\
\end{array}$ \\
\hline PI 1 & & \multicolumn{9}{|c|}{$100 \%$} & $83 \%$ & $17 \%$ \\
\hline PI 2 & & \multicolumn{9}{|c|}{$100 \%$} & $87 \%$ & $13 \%$ \\
\hline PI 3 & & \multicolumn{9}{|c|}{$100 \%$} & $85 \%$ & $15 \%$ \\
\hline PI 4 & & \multicolumn{9}{|c|}{$100 \%$} & $90 \%$ & $10 \%$ \\
\hline \multicolumn{13}{|c|}{ Table 7. Evaluation of PI achievements for PLO7 in comparison with the targets } \\
\hline \multicolumn{2}{|c|}{ PI of PLO7 } & \multicolumn{3}{|c|}{$\%$ of students passing } & \multicolumn{3}{|c|}{$\%$ of students failing } & \multicolumn{3}{|c|}{ Target } & \multicolumn{2}{|c|}{ Evaluation } \\
\hline \multicolumn{2}{|c|}{ PI 1} & \multicolumn{3}{|c|}{$83 \%$} & \multicolumn{2}{|c|}{$17 \%$} & \multicolumn{4}{|c|}{$80 \%$ of students passing } & \multicolumn{2}{|c|}{ Reaching target } \\
\hline \multicolumn{2}{|c|}{ PI 2} & \multicolumn{3}{|c|}{$87 \%$} & \multicolumn{2}{|c|}{$13 \%$} & \multicolumn{4}{|c|}{$85 \%$ of students passing } & \multicolumn{2}{|c|}{ Reaching target } \\
\hline \multicolumn{2}{|c|}{ PI 3} & \multicolumn{3}{|c|}{$85 \%$} & \multicolumn{2}{|c|}{$15 \%$} & \multicolumn{4}{|c|}{$90 \%$ of students passing } & \multicolumn{2}{|c|}{ Not reaching target } \\
\hline \multicolumn{2}{|c|}{ PI 4} & \multicolumn{3}{|c|}{$90 \%$} & \multicolumn{2}{|c|}{$10 \%$} & \multicolumn{4}{|c|}{$95 \%$ of students passing } & \multicolumn{2}{|c|}{ Not reaching target } \\
\hline
\end{tabular}




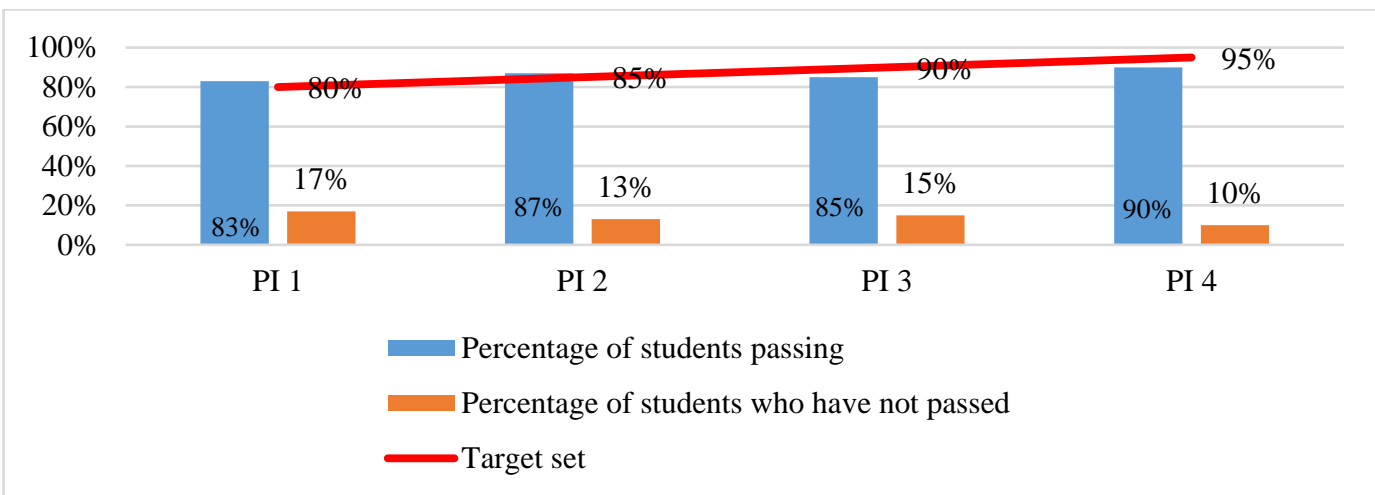

Graph 1. Evaluation of PI achievements for PLO7 in comparison with the targets

\section{DISCUSSION AND CONCLUSION}

Measuring and evaluating the level of students achieving the program learning outcomes is a relatively new issue in Vietnam and has not yet been concerned by lecturers as well as managers of higher education institutions. Through stimulated data, the article presented the method to measure and evaluate the level of students achieving the program learning outcomes. The results of the measurement and evaluation of the level of students achieving the learning outcomes are also an important basis for improving the curriculum content, equipment conditions, facilities, and materials for training, as well as testing and evaluation methods. In addition, the assessment of the level of students achieving the program learning outcomes can also be used to assess the training quality of educational institutions, contributing to improving the prestige and position of higher education institutions to their stakeholders such as family, society, business, and students.

\section{REFERENCES}

Alzubaidi, L. (2017). Programme outcomes assessment using key performance indicators. Proceedings of $62^{\text {nd }}$ ISERD International Conference, Boston, USA.

Ayadi, T., Ahmed, T., Chowdhury, S., Asiz, A. (2020). Measurable performance indicators of student learning outcomes: a case study. Global Journal of Engineering Education, 22(1), 40-50.

Ministry of Education and Training (2010). Correspondent Letter No. 2196/BGDDT-GDDH dated 22/4/2010 on the construction and announcement of learning outcomes.

Ministry of Education and Training (2016). Circular No. 04/2016/TT-BGDDT dated March 14, 2016 promulgating the standards for evaluating the quality of training programs at all levels of higher education.

Biggs, J. \& Tang, C. (2007). Teaching for Quality Learning at University Maidenhead. Open University Press, McGraw Hill.

Biggs, J. B. (1996). Enhancing teaching through constructive alignment. Higher Education, 32, 1-18.

Hoang Thi Huong (2018). Improving the quality of developing learning outcomes in a number of higher education institutions in our country. Vietnam Journal of Education, special issue May 2, 86-89.

Le Ngoc Quynh Lam, Vu The Dung, Do Ngoc Hien, Lam Tuong Thoai, Vu Thi Thuy Trang, Dinh Ngoc Anh (2017). Developing a set of indicators to evaluate the effectiveness of university training programs in the fields of engineering and technology. Science and Technology Development Journal, 20, Book 3, 44-50.

Luu Khanh Linh (2020). Evaluating the learning results of the subjects according to the program learning outcomes to ensure the connection of the components of the teaching process. Vietnam Journal of Education, special issue May 1, 67-72.

Luu Khanh Linh (2020). Research on student assessment and student orientation according to the program learning outcomes of the university-level training program. Vietnam Journal of Education, 483, 6-12.

Sharma, S. K., Tirumalai, S. V., Alhamdan, A. A. (2019). Mathematical models for evaluating programme and course learning outcomes in higher education. International Transaction Journal of Engineering, Management, Applied Sciences \& Technologies, 10(3), 283-297. DOI: 10.14456/ITJEMAST.2019.28

Ong Chee Bin, J. (2018). An integrated AUN-QA and OBE Framework for programme QA. Accessed from http://johnsonongcheebin.blogspot.com/2018/03/an-intergrated-aun-qa-and-obe-framework.html

Tyler, R. W. (1949). Basic principles of training program and instruction. Chicago: The University of Chicago Press. 